\title{
Earnings Management for Second-time IPOs: Evidence from China
}

\author{
Songling Yang ${ }^{1}$, Mengwei $\mathrm{Liu}^{1}$, Hemei $\mathrm{Li}^{2}$, Juncheng $\mathrm{Li}^{3}, \&$ Qiuyue Zhang ${ }^{1}$ \\ ${ }^{1}$ School of Economics and Management, Beijing University of Technology, Beijing, 100124, China \\ ${ }^{2}$ School of Finance, Renmin University of China, Beijing, 100872, China \\ ${ }^{3}$ Institute of Finance and Banking, Chinese Academy of Social Sciences, Beijing, 100028, China \\ Correspondence: Juncheng Li, Institute of Finance and Banking, Chinese Academy of Social Sciences, Beijing, 100028, \\ China.
}

Received: April 28, 2021

Accepted: May 20, $2021 \quad$ Available online: May 26, 2021

doi:10.11114/aef.v8i3.5245

URL: https://doi.org/10.11114/aef.v8i3.5245

\begin{abstract}
In China's IPO market, firms that fail in their first IPO application make considerable adjustments before making their second IPO application. Examining firms that applied for IPOs during 2004-2018, we find that failed IPO applicant firms "package" themselves to obtain approval of the China Securities Regulatory Commission (CSRC) by reducing accrual earnings management and increasing real earnings management. In addition, after a successful second IPO application, these firms relax their vigilance vis-à-vis the CSRC and increase both accrual and real earnings management. This pre-IPO "packaging" behavior deceives investors, leading to higher IPO prices and higher post-IPO returns.
\end{abstract}

Keywords: initial public offering (IPO), second-time IPOs, earnings management; post-IPO performance

JEL classification: G14, G32, M41

\section{Introduction}

In China, firms apply for initial public offerings (IPOs) through sponsors, and the application materials are submitted to the China Securities Regulatory Commission (CSRC) for approval. China's IPO market is moving from being administration-oriented to market-oriented, but approval of the CSRC still plays an important role in the IPO process. During 2004-2018, a total of 2304 firms submitted IPO applications for the first time, of which 173 firms failed to launch an IPO(Note 1). Approximately $92 \%$ of firms see their first IPO applications approved, which we call the "first-time IPOs". For firms with failed applications, the CSRC allows them to submit a second IPO application after a process of rectification. We call the successful entry of such firms to the IPO market a "second-time IPOs".

Second-time IPOs in China are slightly different from those in Western countries. In Western countries, a firm's second IPO application is usually due to unsatisfactory prices for issuers in first-time IPOs (Lian \& Wang, 2009), while in China, it is usually because of poor profitability, poor quality of information disclosure, or other reasons. In China, firms that fail on their first IPO attempt need to make considerable adjustments before applying for an IPO again; these adjustments take a long time. The urgent need to go public and the long-term adjustment process motivate firms to engage in earnings management. However, there is still no answer to whether these firms "package" themselves through earnings management to ensure the success of a second IPO application. Therefore, we try to answer this question, and if earnings management truly exists, we further explore its subsequent impact.

Firms applying for an IPO can "package" themselves due to information asymmetry, which is a serious problem in the IPO market (Tsai \& Huang, 2020). Earnings management refers to the discretionary adjustment of earnings based on different accounting principles. The capital market in China has been developing for only a short time, and the market supervision system is imperfect, leading to widespread earnings management, which can affect both earnings and cash flows (Kałdoński \& Jewartowski, 2020). In China, IPO applicant firms must make profits for three consecutive years and meet certain requirements on accounting indicators such as net assets, leading some firms with poor performance to prefer to carry out pre-IPO earnings management to meet the requirements of sponsors and the CSRC (Aharony et al., 1993, 2000; Dechow \& Skinner, 2000; Cormier \& Martinez, 2006). Pre-IPO earnings management usually leads to price inflation and improves post-IPO performance in the short run (Friedlan, 1994; DuCharme et al., 2001). Earnings management has been widely studied in the IPO market, but few studies pay attention to the difference between 
first-time and second-time IPOs. Second-time IPOs in China are a brand-new study topic. Compared with first-time IPOs, firms with second-time IPOs are more motivated to take measures to "package" themselves, and earnings management is one of them.

Therefore, we divide firms that submitted IPO applications to the CSRC from 2004 to 2018 into first-time and second-time IPO firms and consider the relationship between earnings management and second-time IPOs. Specifically, we try to answer the following questions: Do second-time IPO firms tend to conduct pre-IPO earnings management? Does earnings management change after the IPO? How do second-time IPO firms perform in the short run?

Our paper makes several contributions. First, we distinguish second-time IPO firms from first-time IPO firms and focus on the former, which are a special, rarely studied group of listed firms in China. Second, we explore the relationship between second-time IPOs and earnings management in China, which is of great significance for institutional regulation in the IPO market. Third, we compare IPO pricing and post-IPO performance between first-time and second-time IPO firms.

\section{Data}

Our initial sample consists of 2991 firms that submitted IPO applications to the CSRC from 2004 to 2018 . To classify the sample into first-time and second-time IPOs, we manually collated firms' IPO application results, including "pass", "suspend voting", "cancel approval", "fail", etc., from the WIND database and the CSRC website. We exclude firms with the following features from the initial sample: (a) firms with the "suspend voting" outcome, (b) firms with the "pass but withdraw the public offering" outcome, and (c) financial firms. We thus obtain 2462 IPO firms and 6545 firm-year observations in total. All other data come from the China Stock Market and Accounting Research Database (CSMAR); the variable definitions can be seen in Table 1 .

Second-time IPOs. We define firms that receive CSRC approval of their first application as first-time IPO firms and those that receive CSRC approval of their second application as second-time IPO firms.

Accrual and real earnings management. Following Jones (1991), Dechow et al. (1998), Roychowdhury (2006), and Zang (2012), we measure accrual earnings management and real earnings management (including abnormal cash flow from operation (CFO), abnormal production costs, and abnormal discretionary expenses); see Appendix A.

Relative IPO price. We use the relative IPO price to judge whether second-time IPOs are underpriced or overpriced in the short term. The relative IPO price refers to the ratio of the target firm IPO price to the benchmark firm IPO price. Similar to Prunanandam et al. (2004), we choose firms that meet the following conditions as benchmark firms: (a) listed for more than three years; (b) in the same industry as the target firm; and (c) with similar financial indicators to those of the target firm, including sales, net income, and earnings per share.

Post-IPO returns. We use 90-day, 100-day, and 120-day cumulative market-adjusted returns to express the post-IPO returns in the short run. The market-adjusted return is:

$$
A R_{i, t}=R_{i, t}-M R
$$

where $R_{i, t}$ is the daily return for firm $i$ on day $t$ and the market benchmark return $M R$ is the value-weighted average return of all A-shares. Then, we add up the $n$-day returns after the IPO to obtain the cumulative market-adjusted returns, that is, $C A R_{i}=\sum_{t=1}^{n} A R_{i, t}$, where $n$ indicates different periods, namely, 90 days, 100 days, and 120 days.

Table 1. Variable definitions

\begin{tabular}{|c|c|}
\hline Variable & Definition \\
\hline second & Dummy variable: equals 1 for second-time IPOs and 0 for first-time IPOs \\
\hline$a b s D A$ & $\begin{array}{l}\text { The absolute value of the "abnormal" total accrual, reflecting accrual earnings management in each year before } \\
\text { IPO }\end{array}$ \\
\hline$R M$ & $\begin{array}{l}\text { The total value of the "abnormal" CFO, "abnormal" production costs, and "abnormal" discretionary expenses } \\
\text { reflecting real earnings management in each year before IPO }\end{array}$ \\
\hline$a b C F O$ & Difference between actual CFO and theoretical CFO, reflecting the "abnormal" CFO in each year before IPO \\
\hline$a b P R O D$ & $\begin{array}{l}\text { Difference between actual production costs and theoretical production costs, reflecting the "abnormal" } \\
\text { production costs in each year before IPO }\end{array}$ \\
\hline$a b D I S X$ & $\begin{array}{l}\text { Difference between actual discretionary expenses and theoretical discretionary expenses, reflecting the } \\
\text { "abnormal" discretionary expenses in each year before IPO }\end{array}$ \\
\hline price_ratio & The IPO price of the target firm divided by the IPO price of the benchmark firm \\
\hline CAR_90 & 90-day cumulative market-adjusted returns after IPO \\
\hline CAR_100 & 100-day cumulative market-adjusted returns after IPO \\
\hline CAR_120 & 120-day cumulative market-adjusted returns after IPO \\
\hline size & Natural logarithm of total assets in each year before IPO \\
\hline
\end{tabular}


leverage Total liabilities divided by total assets in each year before IPO

turnover Turnover divided by total shares outstanding (\%)

Tobin_q Market value divided by replacement cost in each year before IPO

$S O E \quad$ Dummy variable: equals 1 for the state-owned firm and 0 otherwise

LMS The total shareholding ratio of the second to tenth largest shareholders

Big4 Dummy variable: equals 1 if auditors belong to the Big Four accounting firms and 0 otherwise

Panel A of Table 2 displays the summary statistics of all variables. Of the 6545 firm-year observations, the proportion of second-time IPO firm-year observations is approximately 6.9\%. For all 6545 observations, there is positive accrual earnings management and negative real earnings management. Additionally, the IPO price is generally higher than the market benchmark IPO price, and the short-run IPO performance is better than the market performance (Note 2). We also employ a $t$-test (Panel B) to evaluate whether pre-IPO accrual or real earnings management is significantly different between first-time and second-time IPO firms. Compared with first-time IPO firms, second-time IPO firms display lower accrual earnings management and higher real earnings management, especially higher "abnormal" production costs.

Table 2. Summary statistics

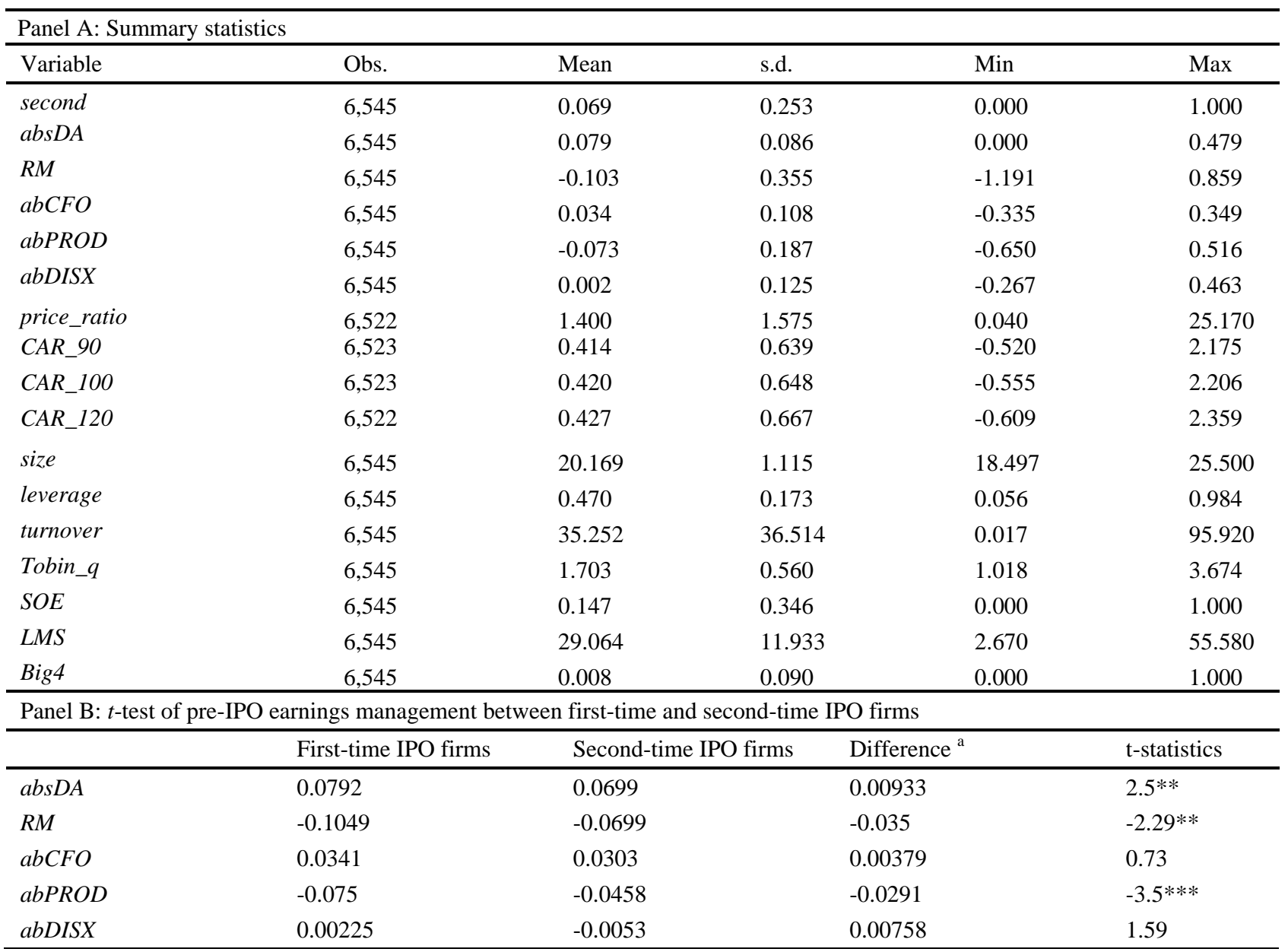

Panel A reports the mean value, standard deviation, and maximum and minimum values of each variable for a total of 6545 firm-year observations. Panel B shows the $t$-test of pre-IPO earnings management between first-time and second-time IPO firms. $* * *, * *$, and * indicate that the coefficient is significant at the levels of $1 \%, 5 \%$, and $10 \%$, respectively.

${ }^{\text {a }}$ First-time IPO firm minus second-time IPO firms. 


\section{Empirical Models and Results}

\subsection{Pre-IPO: "Myopia effect" on Earnings Management}

The failure of an IPO application on the first attempt makes firms more cautious, and to increase the success rate of their IPO applications on the second attempt, firms take various measures, such as earnings management (Aharony et al., 1993; Friedlan, 1994). Thus, we study the relationship between earnings management and second-time IPOs with the following model:

$$
y_{i, t}=\beta_{0}+\beta_{1} \operatorname{second}_{i, t}+\sum_{k} \beta_{k} \operatorname{controls}_{i, t}+\delta_{t}+\varphi_{i}+\epsilon_{i, t}
$$

where $i$ refers to the IPO firm; $t$ refers to each year before the IPO; $y_{i, t}$ is accrual or real earnings management, specifically, "abnormal" CFO, "abnormal" production costs, or "abnormal" discretionary expenses; $\delta_{t}$ represents the time fixed effect; and $\varphi_{i}$ represents the industry fixed effect.

Table 3 shows the model results. From columns (1) and (2) of Panel A, we find that accrual earnings management is usually lower for second-time IPO firms. In column (2) of Panel A, for example, the degree of accrual earnings management of second-time IPO firms is $0.85 \%$ lower than that of first-time IPO firms, a difference that is significant at the $5 \%$ level. Does this mean that the earnings of second-time IPO firms are better? The answer is no. From columns (3) and (4) of Panel A, we learn that second-time IPO firms utilize real earnings management a significant $4.73 \%$ more than first-time IPO firms (in column (4) of Panel A). To reduce the risk of IPO failure, second-time IPO firms have a strong motivation to manipulate earnings upward. To avoid rejection by their underwriters and/or the CSRC, second-time IPO firms choose real earnings management, which is more hidden than accrual earnings management (see Graham et al., 2005; Cohen et al., 2008). However, real earnings management, at the expense of future cash flow, has a more negative impact on the future of firms. We dub this phenomenon the "myopia effect" of second-time IPOs on earnings management.

Next, we analyze the real earnings management behavior of second-time IPO firms in detail, including "abnormal" CFO, "abnormal" production costs, and "abnormal" discretionary expenses (see Panel B of Table 3). We study whether second-time IPO firms present a higher level of (aggregate) real earnings management, and then we explore the main way these second-time IPO firms implement real earnings management. Panel B of Table 3 shows that the second-time IPO harms "abnormal" CFO (not significant), a positive impact on "abnormal" production costs (significant at the $1 \%$ level), and a negative impact on "abnormal" discretionary expenses (significant at the 10\% level). This means that second-time IPO firms manipulate their earnings upward utilizing all three methods, namely, sales manipulation, overproduction, and reduction of discretionary expenditures, among which the main method is reducing discretionary expenditures.

Table 3. Myopia effect of second-time IPOs on earnings management

\begin{tabular}{|c|c|c|c|c|}
\hline & $\begin{array}{l}(1) \\
a b s D A\end{array}$ & $\begin{array}{l}(2) \\
a b s D A\end{array}$ & $\begin{array}{l}(3) \\
R M\end{array}$ & $\begin{array}{l}(4) \\
R M\end{array}$ \\
\hline second & $\begin{array}{l}-0.0117 * * * \\
(-2.90)\end{array}$ & $\begin{array}{l}-0.0085^{* *} \\
(-2.13)\end{array}$ & $\begin{array}{l}0.0421 * * \\
(2.45)\end{array}$ & $\begin{array}{l}0.0473 * * * \\
(2.80)\end{array}$ \\
\hline size & & $\begin{array}{l}-0.0083 * * * \\
(-6.70)\end{array}$ & & $\begin{array}{l}-0.0316^{* * * *} \\
(-6.00)\end{array}$ \\
\hline leverage & & $\begin{array}{l}-0.0071 \\
(-1.00)\end{array}$ & & $\begin{array}{l}0.4791 * * * \\
(16.02)\end{array}$ \\
\hline turnover & & $\begin{array}{l}0.0001 * * \\
(2.02)\end{array}$ & & $\begin{array}{l}-0.0001 \\
(-0.19)\end{array}$ \\
\hline Tobin_q & & $\begin{array}{l}0.0129 * * * \\
(5.54)\end{array}$ & & $\begin{array}{l}0.0172 * \\
(1.75)\end{array}$ \\
\hline$S O E$ & & $\begin{array}{l}-0.0018 \\
(-0.54)\end{array}$ & & $\begin{array}{l}0.0133 \\
(0.96)\end{array}$ \\
\hline$L M S$ & & $\begin{array}{l}0.0002 * * \\
(2.48)\end{array}$ & & $\begin{array}{l}-0.0003 \\
(-0.91)\end{array}$ \\
\hline Big4 & & $\begin{array}{l}-0.0062 \\
(-0.55)\end{array}$ & & $\begin{array}{l}0.0723 \\
(1.51)\end{array}$ \\
\hline Constant & $\begin{array}{l}0.0503 \\
(0.60)\end{array}$ & $\begin{array}{l}0.2039 * * \\
(2.35)\end{array}$ & $\begin{array}{l}-0.2059 \\
(-0.58)\end{array}$ & $\begin{array}{l}0.3150 \\
(0.86)\end{array}$ \\
\hline Observations & 6,545 & 6,545 & 6,545 & 6,545 \\
\hline Adjusted R-squared & 0.094 & 0.118 & 0.036 & 0.073 \\
\hline Year Fixed Effect & Yes & Yes & Yes & Yes \\
\hline
\end{tabular}




\begin{tabular}{|c|c|c|c|c|c|c|}
\hline \multirow{2}{*}{\multicolumn{7}{|c|}{ 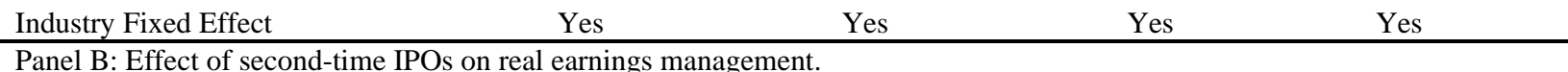 }} \\
\hline & & & & & & \\
\hline & (1) & (2) & (3) & (4) & (5) & (6) \\
\hline & $a b C F O$ & $a b C F O$ & $a b P R O D$ & $a b P R O D$ & $a b D I S X$ & $a b D I S X$ \\
\hline \multirow[t]{2}{*}{ second } & -0.0040 & -0.0045 & $0.0328 * * *$ & $0.0323 * * *$ & -0.0087 & $-0.0116^{*}$ \\
\hline & $(-0.76)$ & $(-0.88)$ & $(3.61)$ & $(3.65)$ & $(-1.47)$ & $(-1.95)$ \\
\hline \multirow[t]{2}{*}{ size } & & $0.0146^{* * *}$ & & -0.0044 & & $0.0123^{* * *}$ \\
\hline & & $(9.17)$ & & $(-1.61)$ & & $(6.68)$ \\
\hline \multirow[t]{2}{*}{ leverage } & & $-0.1676 * * *$ & & $0.2893 * * *$ & & $-0.0415 * * *$ \\
\hline & & $(-18.50)$ & & $(18.47)$ & & $(-3.95)$ \\
\hline \multirow[t]{2}{*}{ turnover } & & -0.0000 & & -0.0001 & & -0.0001 \\
\hline & & $(-0.33)$ & & $(-1.02)$ & & $(-1.09)$ \\
\hline \multirow[t]{2}{*}{ Tobin_q } & & $0.0130^{* * *}$ & & -0.0018 & & $-0.0110^{* * *}$ \\
\hline & & $(4.37)$ & & $(-0.36)$ & & $(-3.18)$ \\
\hline \multirow[t]{2}{*}{$S O E$} & & -0.0003 & & 0.0085 & & -0.0043 \\
\hline & & $(-0.08)$ & & $(1.16)$ & & $(-0.89)$ \\
\hline \multirow[t]{2}{*}{$L M S$} & & 0.0002 & & -0.0002 & & 0.0002 \\
\hline & & $(1.32)$ & & $(-0.86)$ & & $(1.21)$ \\
\hline \multirow[t]{2}{*}{ Big4 } & & $-0.0338 * *$ & & 0.0249 & & -0.0031 \\
\hline & & $(-2.33)$ & & $(0.99)$ & & $(-0.19)$ \\
\hline \multirow[t]{2}{*}{ Constant } & 0.0461 & $-0.2444 * *$ & -0.1469 & -0.1359 & 0.0132 & $-0.2325^{*}$ \\
\hline & $(0.42)$ & $(-2.20)$ & $(-0.78)$ & $(-0.71)$ & $(0.11)$ & $(-1.81)$ \\
\hline Observations & 6,545 & 6,545 & 6,545 & 6,545 & 6,545 & 6,545 \\
\hline Adjusted & 0.025 & 0.082 & 0.023 & 0.081 & 0.065 & 0.076 \\
\hline Year Fixed Effect & Yes & Yes & Yes & Yes & Yes & Yes \\
\hline $\begin{array}{l}\text { Industry } \quad \text { Fixed } \\
\text { Effect }\end{array}$ & Yes & Yes & Yes & Yes & Yes & Yes \\
\hline
\end{tabular}

Panel A presents the effect of second-time IPOs on accrual and (aggregate) real earnings management. Further, we explore the effect of second-time IPOs on three kinds of real earnings management in Panel B. For each model, we implement two kinds of regression (with and without control variables), and all regressions include both year and industry fixed effects. $* * *, * *$, and $*$ indicate that the coefficient is significant at the level of $1 \%, 5 \%$, and $10 \%$, respectively; the number in parentheses is the t-statistic.

\subsection{Post-IPO: "Reversal effect" on Accrual Earnings Management}

Due to the strong motivation to secure a successful IPO, second-time IPO firms choose real earnings management instead of accrual earnings management before their IPOs. However, it is crucial to determine whether this practice continues after the IPO. In this subsection, we study second-time IPO firms only. Panel A of Table 4 reports $t$-test results for earnings management among second-time IPO firms pre-and post-IPO. We find that compared with pre-IPO firms, second-time IPO firms exhibit both significantly higher post-IPO accrual and real earnings management, especially in terms of "abnormal" CFO and "abnormal" production costs. Before second-time IPOs, these firms reduce accrual earnings management to comply with IPO conditions, but this situation does not last, and they increase accrual earnings management soon after second-time IPOs. We call this the "reversal effect" on accrual earnings management.

We also test this reversal effect for second-time IPO firms using the following model:

$$
y_{i, t}=\beta_{0}+\beta_{1} \text { flag }_{i, t}+\sum_{k} \beta_{k} \text { controls }_{i, t}+\delta_{t}+\varphi_{i}+\epsilon_{i, t}
$$

where flag $_{i, t}$ is a dummy variable that equals 0 in the pre-IPO period and 1 in the post-IPO period and $y_{i, t}$ refers to accrual or (aggregate) real earnings management. Panel B of Table 4 shows that the post-IPO variable has a significantly positive effect on accrual and real earnings management, meaning that both accrual and real earnings management increase after second-time IPOs. In columns (2) and (4), for example, accrual earnings management increases by $3.08 \%$ (significant at the $1 \%$ level) after a successful IPO, and real earnings management increases by $15.38 \%$ (significant at the $1 \%$ level) after a successful IPO. We conclude that the myopia effect does not continue after IPO; worse, second-time IPO firms have an incentive to reverse their low level of accrual earnings management, and real earnings management continues to increase. This may be because Chinese investors are not sophisticated enough to catch earnings manipulation, allowing firms to report upward-biased earnings for a long period. 
Table 4. Reversal effect of earnings management for second-time IPO firms

\begin{tabular}{|c|c|c|c|c|}
\hline & Pre-IPO & Post-IPO & Difference $^{\mathrm{a}}$ & t-statistics \\
\hline$a b s D A$ & 0.0676 & 0.0769 & -0.0093 & $-1.88 * *$ \\
\hline$R M$ & -0.0671 & 0.0469 & -0.114 & $-6.90 * * *$ \\
\hline$a b C F O$ & 0.0283 & -0.0163 & 0.0446 & $7.92 * * *$ \\
\hline$a b P R O D$ & -0.0445 & 0.0232 & -0.0677 & $-7.57 * * *$ \\
\hline$a b D I S X$ & -0.0051 & -0.0072 & 0.0021 & 0.4 \\
\hline \multicolumn{5}{|c|}{ Panel B: Reversal effect of earnings management in pre-and post-IPO periods (second=1) } \\
\hline & $(1)$ & $(2)$ & (3) & (4) \\
\hline & $a b s D A$ & $a b s D A$ & $R M$ & $R M$ \\
\hline flag & $\begin{array}{l}0.0179 * * * \\
(2.90)\end{array}$ & $\begin{array}{l}0.0308 * * * \\
(4.06)\end{array}$ & $\begin{array}{l}0.0982 * * * \\
(5.23)\end{array}$ & $\begin{array}{l}0.1538 * * * \\
(6.81)\end{array}$ \\
\hline size & & $\begin{array}{l}-0.0052 * \\
(-1.69)\end{array}$ & & $\begin{array}{l}-0.0408 * * * \\
(-4.42)\end{array}$ \\
\hline leverage & & $\begin{array}{l}0.0692 * * * * \\
(4.37)\end{array}$ & & $\begin{array}{l}0.3084 * * * \\
(6.55)\end{array}$ \\
\hline turnover & & $\begin{array}{l}0.0001 \\
(0.69)\end{array}$ & & $\begin{array}{l}0.0000 \\
(0.16)\end{array}$ \\
\hline Tobin_q & & $\begin{array}{l}0.0037 \\
(0.67)\end{array}$ & & $\begin{array}{l}-0.0723 * * * \\
(-4.33)\end{array}$ \\
\hline$S O E$ & & $\begin{array}{l}-0.0174 * * \\
(-2.28)\end{array}$ & & $\begin{array}{l}-0.0725 * * * \\
(-3.19)\end{array}$ \\
\hline$L M S$ & & $\begin{array}{l}0.0005 * * \\
(2.36)\end{array}$ & & $\begin{array}{l}-0.0038 * * * \\
(-6.33)\end{array}$ \\
\hline Big4 & & $\begin{array}{l}-0.0265 \\
(-1.30)\end{array}$ & & $\begin{array}{l}-0.0112 \\
(-0.18)\end{array}$ \\
\hline Constant & $\begin{array}{l}0.0646 \\
(1.44)\end{array}$ & $\begin{array}{l}0.1182 \\
(1.59)\end{array}$ & $\begin{array}{l}-0.0099 \\
(-0.07)\end{array}$ & $\begin{array}{l}0.6730 * * * * \\
(3.05)\end{array}$ \\
\hline Observations & 1,630 & 1,630 & 1,630 & 1,630 \\
\hline Adjusted R-squared & 0.068 & 0.084 & 0.040 & 0.099 \\
\hline Year Fixed Effect & Yes & Yes & Yes & Yes \\
\hline Industry Fixed Effect & Yes & Yes & Yes & Yes \\
\hline
\end{tabular}

Panel A shows the $t$-test of earnings management of second-time IPO firms between the pre-and post-IPO periods. Panel B shows the regression model identifying the reversal effect on earnings management among second-time IPO firms. For each model, we implement two kinds of regression (with and without control variables), and all regressions include both year and industry fixed effects. ***, *, and * indicate that the coefficient is significant at the level of $1 \%$, $5 \%$, and $10 \%$, respectively; the number in parentheses is the t-statistic.

a Pre-IPO minus post-IPO.

\subsection{IPO Pricing and Post-IPO Returns of Second-Time IPO Firms}

First, we compare the IPO pricing of second-time and first-time IPO firms. The aggressive earnings management of second-time IPO firms can strengthen their bargaining power, which improves the performance of IPO pricing for these firms. To evaluate whether the IPO price of second-time IPO firms is higher, we design the model for IPO pricing as follows:

$$
\text { price_ratio }_{i, t}=\beta_{0}+\beta_{1} \text { second }_{i, t}+\sum_{k} \beta_{k} \text { controls }_{i, t}+\delta_{t}+\varphi_{i}+\epsilon_{i, t}
$$

where price_ratio $_{i, t}$ is the relative IPO price. Next, we predict that as investors are deceived by the earnings management of second-time IPO firms, post-IPO returns should remain high in the short run. To prove this, we employ the following models:

$$
\operatorname{Return}_{i, t}=\beta_{0}+\beta_{1} \operatorname{second}_{i, t}+\sum_{k} \beta_{k} \operatorname{controls}_{i, t}+\delta_{t}+\varphi_{i}+\epsilon_{i, t}
$$

where Return $_{i, t}$ represents post-IPO cumulative returns with different holding periods, namely, CAR_90, CAR_100, and CAR_120.

Panel A of Table 5 displays the effect of the second-time IPO on the relative IPO price for Eq. (4). In column (2), we find that the second-time IPO price is $22.73 \%$ higher than the first-time IPO price (significant at the $1 \%$ level). This may be due to earnings management activities before the IPO. Panel B displays the effect of second-time IPOs on post-offer returns for Eq. (5). All coefficients of second on returns are significantly positive at a 5\% level, indicating 
that second-time IPO firms exhibit higher post-IPO returns than first-time IPO firms. We can conclude that the better pre-IPO earnings status of second-time IPO firms deceives investors, yielding higher IPO prices and better post-IPO returns in the short run.

Table 5. IPO pricing and post-IPO returns of second-time IPOs

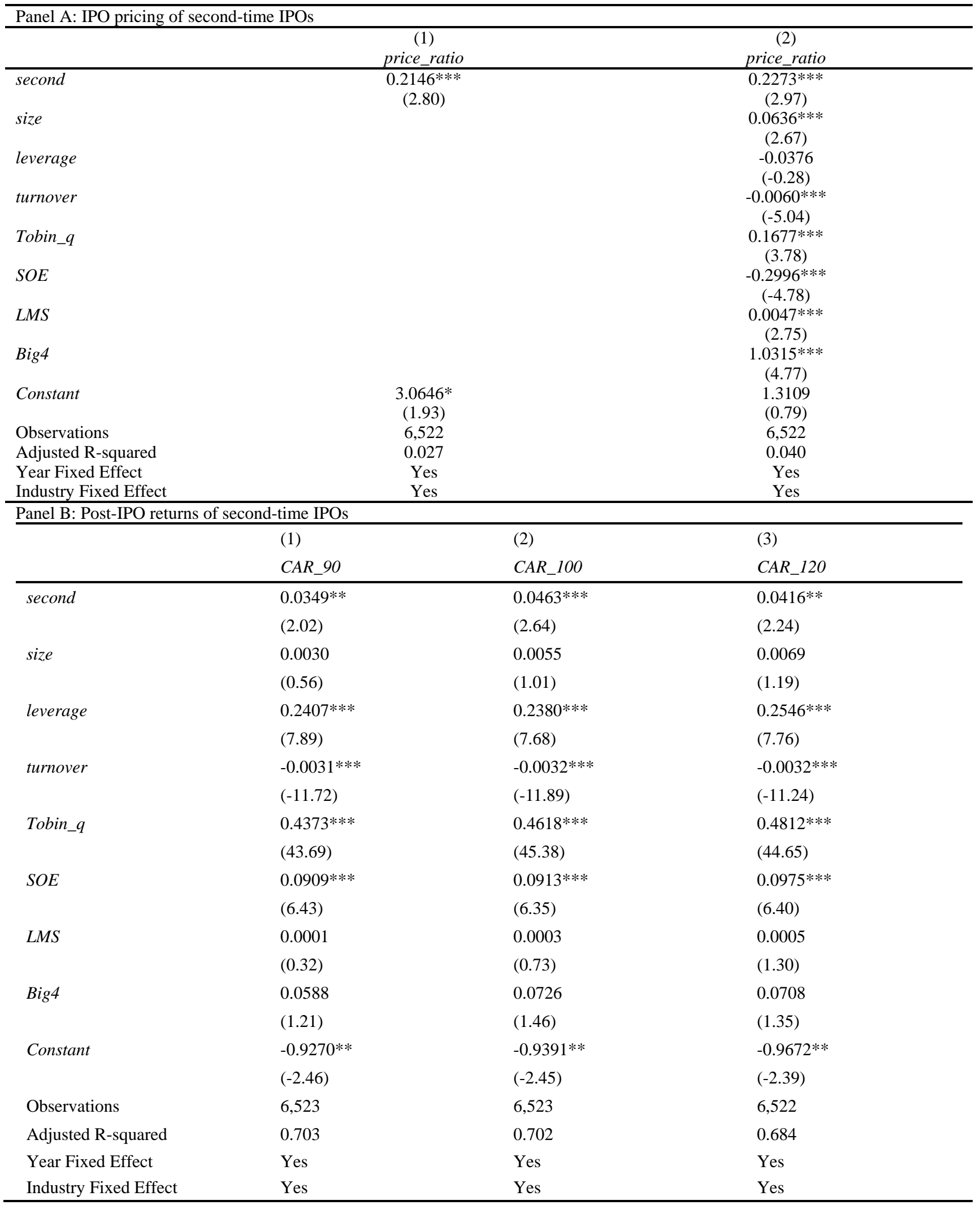


Panel A shows the effect of second-time IPOs on IPO pricing. We implement two kinds of regression: with and without control variables. Panel B reports the short-run IPO returns of second-time IPO firms, specifically, the 90-day, 100-day, and 120-day returns. All regressions include both year and industry fixed effects. ***,**, and * indicate that the coefficient is significant at the level of $1 \%, 5 \%$, and $10 \%$, respectively; the number in parentheses is the t-statistic.

\section{Conclusion}

In China's IPO market, the CSRC plays an important role in the IPOs of firms. If an IPO application fails to be approved, the firm needs to improve itself and resubmit the IPO application to the CSRC after rectification. To assess whether second-time IPO firms employ earnings management to improve the likelihood of a successful IPO, we take firms that submitted IPO applications over the period from 2004 to 2018 as the sample and distinguish second-time from first-time IPO firms. We compare the accrual and real earnings management of these two kinds of IPO firms before they go public and find that the second-time IPO firms "package" themselves through earnings management, in what we call the myopia effect. To ensure a successful IPO, firms that fail in their first-time IPO application prefer to reduce accrual earnings management and increase real earnings management.

Second, we study accrual and real earnings management post-IPO for second-time IPO firms and find a reversal effect on accrual earnings management: after a successful IPO, second-time IPO firms relax their vigilance vis-à-vis CSRC supervision and increase both accrual and real earnings management.

Third, by comparing the IPO pricing and post-IPO returns of first-time and second-time IPO firms, we conclude that the "packaging" behavior of second-time IPO firms improves their IPO price and post-IPO returns in the short run.

\section{References}

Aharony, J., Lee, C. J., \& Wong, T. J. (2000). Financial packaging of IPO firms in China. Journal of Accounting Research, 38(1), 103-126. https://doi.org/10.2139/ssrn.201093

Aharony, J., Lin, C. J., \& Loeb, M. P. (1993). Initial public offerings, accounting choices, and earnings management. Contemporary Accounting Research, 10(1), 61-81. https://doi.org/10.1111/j.1911-3846.1993.tb00382.x

Cohen, D. A., Dey, A., \& Lys, T. Z. (2008). Real and accrual-based earnings management in the pre-and post-Sarbanes-Oxley periods. The Accounting Review, 83(3), 757-787. https://doi.org/10.2308/accr.2008.83.3.757

Cormier, D., \& Martinez, I. (2006). The association between management earnings forecasts, earnings management, and stock market valuation: Evidence from French IPOs. The International Journal of Accounting, 41(3), 209-236. https://doi.org/10.1016/j.intacc.2006.07.004

Dechow, P. M., Kothari, S. P., \& Watts, R. L. (1998). The relation between earnings and cash flows. Journal of Accounting and Economics, 25(2), 133-168. https://doi.org/10.1016/S0165-4101(98)00020-2

Dechow, P. M., \& Skinner, D. J. (2000). Earnings management: Reconciling the views of accounting academics, practitioners, and regulators. Accounting Horizons, 14(2), 235-250. https://doi.org/10.2308/acch.2000.14.2.235

DuCharme, L. L., Malatesta, P. H., \& Sefcik, S. E. (2001). Earnings management: IPO valuation and subsequent performance. Journal of Accounting, Auditing \& Finance, 16(4), 369-396. https://doi.org/10.1177/0148558X0101600409

Friedlan, J. M. (1994). Accounting choices of issuers of initial public offerings. Contemporary Accounting Research, 11(1), 1-31. https://doi.org/10.1111/j.1911-3846.1994.tb00434.x

Graham, J. R., Harvey, C. R., \& Rajgopal, S. (2005). The economic implications of corporate financial reporting. Journal of Accounting and Economics, 40(1), 3-73. https://doi.org/10.1016/j.jacceco.2005.01.002

Jones, J. J. (1991). Earnings management during import relief investigations. Journal of Accounting Research, 29(2), 193-228. https://doi.org/10.2307/2491047

Kałdoński, M., \& Jewartowski, T. (2020). Do firms using real earnings management care about taxes? Evidence from a high book-tax conformity country. Finance Research Letters, 35, 101351. https://doi.org/10.1016/j.frl.2019.101351

Lian, Q., \& Wang, Q. (2009). Does the market incorporate previous IPO withdrawals when pricing second-time IPOs? Financial Management, 38(2), 357-380. https://doi.org/10.1111/j.1755-053X.2009.01039.x

Roychowdhury, S. (2006). Earnings management through real activities manipulation. Journal of Accounting and Economics, 42(3), 335-370. https://doi.org/10.1016/j.jacceco.2006.01.002

Tsai, Y. L., \& Huang, H. (2020). Does IFRS reduce IPO underpricing? Evidence from China. Finance Research Letters, 101673. https://doi.org/10.1016/j.frl.2020.101673

Zang, A. Y. (2012). Evidence on the trade-off between real activities manipulation and accrual-based earnings 
management. The Accounting Review, 87(2), 675-703. https://doi.org/10.2308/accr-10196

\section{Notes}

Note 1. Data are collected manually from the WIND database and the CSRC website.

Note 2. From Panel B of Table 2, we can see that the mean value of the relative IPO price in our sample is 1.4, which is greater than 1 ; the mean values of $C A R \_90, C A R \_100, C A R \_120$ are greater than 0 .

\section{Copyrights}

Copyright for this article is retained by the author(s), with first publication rights granted to the journal.

This is an open-access article distributed under the terms and conditions of the Creative Commons Attribution license which permits unrestricted use, distribution, and reproduction in any medium, provided the original work is properly cited. 